\title{
Distribution of Wild and Cultivated Grapes in Turkey
}

\author{
Ibrahim H. UZUN, Arzu BAYIR
}

Akdeniz University, Faculty of Agriculture, Antalya, Turkey; uzun@akdeniz.edu.tr

\begin{abstract}
Turkey is one of main gene centers in the world for grapes. It is believed that cultivated grapes have their origins in Turkey and the surrounding countries. Vitis vinifera ssp sylvestris is the only wild grape species in this region. That is why Turkey has a very large amount of wild grapevine populations and grape cultivars which offer to grapevine breeders a valuable gene pool. Wild grapevines have significant characters for inducing the resistence to biotic and abiotic stress factors, such as resistance to lime, drought, pests and diseases. Turkey has over 1.600 local grape cultivars, among which the majority of them are conserved at the national grape collection vineyard in Tekirdağ. They are mostly used as table grapes, dried grapes or for local consumptions. Wild grapes are distributed all over the country territory, mainly in the river basins and forests. Wild grape collection vineyards were established at some universities in Turkey. These grapevines will be screened for the resistance to biotic and abiotic stress factors.
\end{abstract}

Keywords: wild grapes, grape cultivars, Turkey

\section{Introduction}

Turkey has a big peninsula named Anatolia which is bounded by the Mediterranean, Black and Aegean seas. Land is joined with the Asian continent to the east and also to Caucasian to the east-northern corner, which is believed to be the primary origin of cultivated grapes. Anatolia is including the area of origin of Vitis vinifera ssp. sylvestris (wild grape) which can be found all over the country especially on river banks, shore of lakes and forests. Anatolia is also called Asia Minor.

Russian botanist Vavilov recognized eight centers of origin for cultivated plants in the world. Turkey-Iran and Mediterranean centers are overlapped in Turkey. These two regions have a key role in the emergence of cereals and horticultural crops including grapes (Anonymous, 2007).

The grape genus Vitis comprises three natural groups based on geographical location: North America, Eurasia and Asia. Botanists list from 25 up to 30 species of American origin, about the same number for Asia, but only a single species for Euroasia: Vitis vinifera. It is cultivated throughout the world today. In contrast with the American and Asiatic vines, the wild populations of Vinifera in Europe are now almost extinct, occurring in widely separated clumps, often reduced to a few vines in protected localities (Mc Govern et al., 2004). In the 1980's, V. sylvestris was added to the IUCN (International Union for Conservation of Nature) list of endangered European plants (Imazio et al., 2009).

European wild grapevine (Vitis vinifera ssp sylvestris Gmelin) has considerable declined. Wild grapevines are being endangered in their natural habitats and high priorities are given to the collection and Vitis germplasm. $V$. vinifera ssp sylvestris species need to be secured in order to conserve and provide genetic resources. The present popu- lations of European ssp. sylvestris are believed to descent from Pleistocene populations. The oldest fossils surely attributed to the wild and cultivated grapevine date back to this period (approx. 1 million years ago), while other species of the genus Vitis are considered to be part of the European fossil flora from the beginnings of Eocene, 40 millions years ago (Tsvetkov et al., 2005).

Formerly, botanists regarded wild grapes of Vitis vinifera as an independent species: Vitis sylvestris C.C. Gmelin. But since these wild forms show close morphological similarity and are interconnected with the cutivated grape, most botanists regard the wild $V$. sylvestris grape vines today as the wild race of cultivated crops. They place them as subspecies of V. sylvestris (C.C. Gmelin) Berger. Sylvestris grapes are widely distributed from the Atlantic coast of Europe to Tadzhikstan and western Himalayas (Fig. 1). But there can be little doubt that $V$. sylvestris vines are indigenous of Southern Europe, the Near East or Southern Caspian belt (Zohary and Hopf, 2000). Scienza et al. (1994) denoted that $V$. vinifera ssp sylvestris and sativa should be regarded as two separate taxa. The boundary between the cultivated grapevine clones and wild forms is blurred by the presence of escapees and secondary derivatives of hybridization. Spontaneous crossings between wild plants and cultivars have been found repeatedly where $V$. sylvestris vines grow in close proximity to vineyards and the F1 hybrids are fully fertile. Therefore, for $V$. vinifera it face in Mediterranean basin with a variable complex of wild forms (growing in primary habitats), escapees, and seedpropagated weedy types (which occur mainly in disturbed surroundings) and cultivated clones (Zohary and Hopf, 2000).

It is formerly accepted that $V$. vinifera $L$. is indigenous to the region between the south of Black Sea and Caspian Sea (Negi and Olmo, 1970). But analyses of sylvestris 


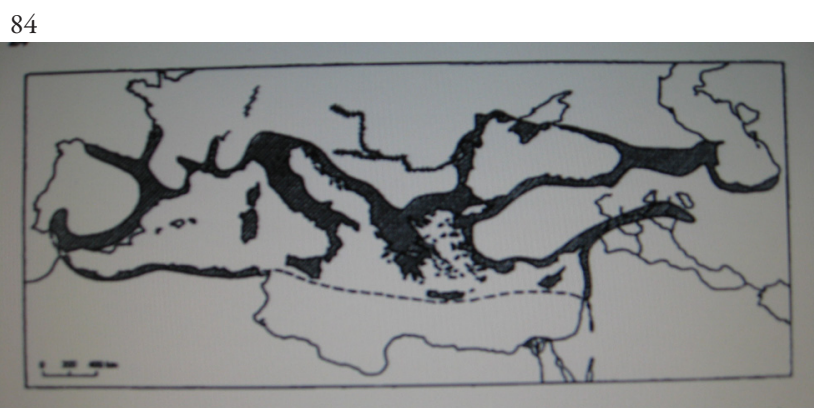

Fig. 1. Distribution of sylvestris in mediterranean basin(after Zohary, 2004)

and sativa genotypes by molecular markers show that the existence of at least two important origin centers for the cultivated germplasm, one in the near east and another in the western Mediterranean region, is to be taken into consideration. Results of microsatellite analysis show that central Mediterranean and Eastern populations have higher diversity values than Western populations. These results are in agrement with Negrul's theory proposing the Anatolian peninsula and Transcaucasian regions as the diversity centre of Vitis vinifera, based on phenotypic variation (Arroyo-Garcia et al., 2006).

Grassi et al. (2003) stated that wild grapevines were first domesticated in Transcaucasian region or Near East region, starting from the second half of the $4^{\text {th }}$ millennium $\mathrm{BC}$. Domesticated grapevines appeared during the first half of $3^{\text {rd }}$ millennium BC in Asia Minor, Southern Greece, Creete and Cyprus, and at the beginning of the $2^{\text {nd }}$ millennium BC in Southern Balkans. The appearance of wild grapevines in Northern Italy, Southern France, Spain and Portugal took place in the second half of the 1 st millennium. Scientist analysed wild and cultivated Italian accessions by SSR markers and found that two cultivars were very close to some wild accessions. That is why they claimed that a secondary grapevines taming occurred in Italy.

Troshin et al. (1990) stated that the principal origin centre of the cutivated grapes is the east Mediterranean region from where grapevine moved to the eastern, northern and western parts of Eurasia and also to the south of Africa, following the great trade ways of the ancient civilizations and the migrations of ancient tribes. A method of mathematical statistics for evaluation of taxonomic usefulness of the characters of $V$. vinifera ssp. sativa cultivars cluster was developed.

Imazio et al. (2009) emphasized that Caucasian region is possible to be the origin centre of $V$. sylvestris. The distribution of the wild grapevine has dramaticaly reduced over the last 150 years with the spread of pathogens from North America (phylloxera, oidium and mildew). Currently, other events impose further threats to its biodiversity; these include the fragmentation of habitats, essentially due to intensive river management, forest cuttings, removal of lianas, on which wild grapevine branches climb. In former centuries, wild grapevine colonized a broad range of habi- tats and soils in the Mediterranean area and in a few sites in central Europe. It should be emphasized that the risk of collecting cultivated varieties is very low, since these plants have very low chances to survive in the wild. To further reduce the risk, only diocious individuals should be collected. Phylogenetic analyses of $V$. sylvestris by DNA techniques show that Caucasian (Armenia) and Turkish wild grapevines belong to the same group, but they are quite different than European sylvestris grapes.

Maghradze et al. (2009) pointed out by archaeological excavations, dating back to the VI-V millennium BC, and by this he evidenced the existence of grape seeds and other plants remains, widely dispersed in Georgia, combined with materials relating to viticulture and wine making activities.

This et al. (2008) found that wild compartments of $V$. vinifera which is the only species of grapevine endemic of Europe has fifteen wild vine in Pic Saint Loup and showed separate sexology on plants, with the majority of vines that were male (58\%).

Anzai et al. (1989), mentioned that male/female ratio of Italian wild grapevine population is 1.8 , with few hermaphrodite examples (2\%). Also, they informed that wild vines grow all over the country up to an altitude of 800 $1000 \mathrm{~m}$ above sea level. They indicated that the predominant berry color is black, but at the rate of $9 \%$ is in white color in sampled vines. The leaves of Italian wild grapes generally have 3 lobes, but 5-7 lobed or no lobated plants were found too.

The first cultivar names were given by Romans, but it was difficult to relate them to modern grapes. The flowering intervals of wild individuals are different from the flowering times of cultivated forms, reducing the possibility of gene flow through pollen (This et al., 2006).

Oceta et al. (2008), explained that $V$. sylvestris is still not protected in most European countries, even if it was added to the IUCN (International Union for Conservation of Nature) list of endangered species. They claimed that hermaphrodite individuals found in European forests are usually escaped cultivars. They detected no sign of ferric chlorosis in wild grapevine populations grown on calcareous soils with high percentage of active limestone (on average $40 \%$ ). They observed variations between wild and cultivated grapevines on the same region, but the differences between male an female individuals of wild grapevines were not significant. Leaves which were inoculated with Uncinula necator and Plasmophara viticola have had the same infection symptoms on both male and females plants of wild grapevines, but the infections were significantly lower than that of the cultivars. Laboratory tests suggested that wild populations have a relative tolerance to both diseases.

Vecchi-Staraz et al. (2009) showed that most of the fertilizing pollen could be assigned to wild males growing nearby. Pollen immigration from cultivated compartment ranges from $4.2 \%$ to $26 \%$, depending on nearby vineyards 
and the kind of hidden pollinators, such as cultivars and rootstocks escaped from farms. In addition, the distance between individuals affects the percentage of the pollen flow. These pollen fluxes may have a significant effect on the evolution of wild populations.

Jacquat and Martinoli (1999), compared different methods such as Stummer's index and formulae of Mangafa and Kotsakis to identify wild and cultivated grapevine populations, using charred grape pips obtained from Petra excavations in Jordan. They decided that most of these pips belong to wild grapevines. They highlighted that pips from cultivated grapes become smaller and rounder when charred. And also, the sylvestris type pip morphology can be associated not only with the wild grapevines, but also with the archaic varieties. They indicated that from a phyto-geographic point of view, wild grapevines are widely distributed from Spanish and French Atlantic coast to Tajikistan, but they are absent in today's territory of Jordan. They are abundant in Mediterranean basin and also in the south of Black and Caspian Seas.

Among the thousand of cultivated grapevines clones and among the variable wild populations, the range of variation in the pip morphology is enormous. For this reason pip shape can not be regarded as a safe diagnostic trait for distinguishing between the wild and cultivated remains in archaeological excavations (Zohary and Hopf, 2000).

The first evidence for grapevine production in the region comprising Turkey, Syria, Iraq and Iran goes back to the mid-sixth millennium BC; by the mid-fifth millennium the vine had come under cultivation, and the domesticated forms appeared later. The earliest evidence for grapes used in wine comes from sixth-millennium BC in Hajji Firuz, Iran. The present distribution of the wild ancestors of the European wine grape (V. vinifera ssp. sylvestris) was established during the early to mid-Holocene

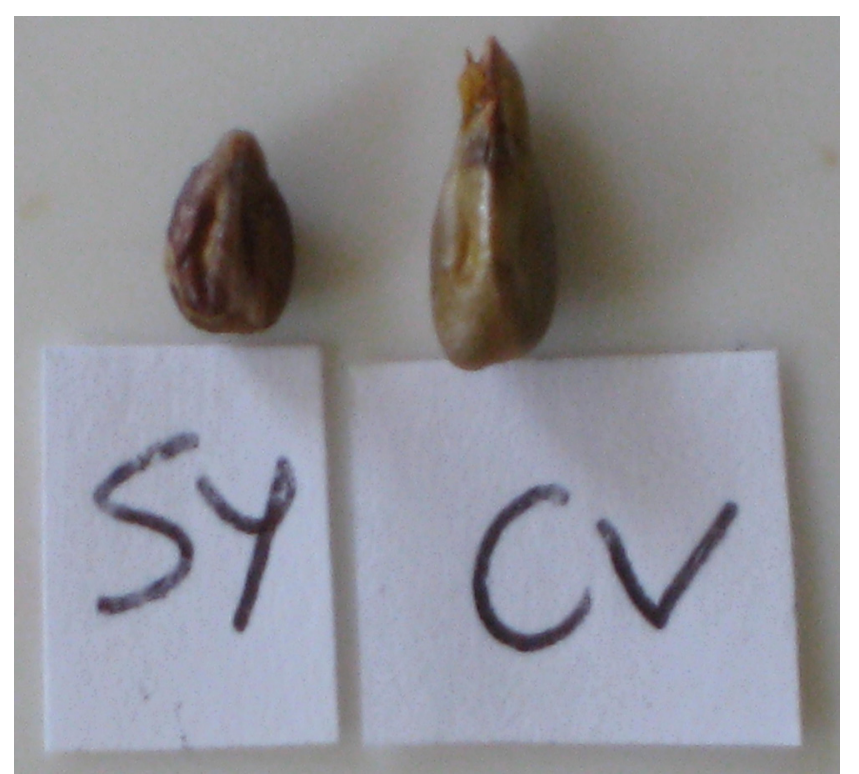

Fig. 2. Comparison of seeds of sylvestris(sy) and grape cultivar(cv). (beginning $11500 \mathrm{cal} \mathrm{BP).} \mathrm{It} \mathrm{is} \mathrm{likely} \mathrm{that} \mathrm{grape} \mathrm{was} \mathrm{do-}$ mesticated in western Asia towards the eastern end of this region (Miller, 2008)

Consequently, there are mainly two phenotypic characters to differentiate the wild and cultivated grapevines:

-Sex of flowers: The wild form is dioecious, while the domesticated forms usually have hermaphrodit flowers.

-Seed morphology: Seeds obtained from wild grapes have short beaks and round in shape while compared eith the cultivated ones that have long beaks (Fig. 2).

\section{Archaeological findings and distribution of wild grapevines in Turkey}

Turkey has a very large amount of wild grapevines and grape cultivars which offers to grapes breeders a valuable gene pool from where to extract genes of ineterst. Turkey has only Vitis vinifera ssp. sylvestris as a wild grape. Wild grapes have valuable features regarding the biotic and abiotic stress factors such as resistance to lime, drought, pest and disease. That is why they are of great interest for researchers and many studies have been made to determine their distribution in Turkey. Here are given localities from where wild grapevines were described by many scholars durin the last 60 years (Tab. 1). It has been mostly investigated from the viti- and viniculture point of view, and also archaeology, in Turkey and vicinity. Wild grapes are distributed all over the country, mainly in river basins and forests. Wild grapes have distinct characters when compared to seedlings of cultivated grapes. Wild grape collection vineyards compressing nearly 1000 genotypes were established at several üniversities. These grapevines will be screened for the resistance to biotic and abiotic stress factors.

The oldest wild grape seed was found at Nevali Çori excavations in Hilvan province of Urfa in Turkey, dated back to 8.400 BP (Before Present) (Güner et al., 2009). Recently, many carbonized and mineralized form of Vitis seeds and fruits have been found in Oküzini and Karain $\mathrm{B}$ caves excavations in Antalya. They comprise four epipalaeolithic levels. Grape remains have been found at archeological unit II (15.460-14.610 uncal BP) and IV (12.260-12.130 uncal BP). Grape berries were found as whole or fragments. The fruits were globular often with a wrinkled surface. The presence of the pentagonal peduncle scar or of a part of seeds embedded in the fruit flesh was noticed. The grape pips were small, subglobuse to hearthshaped and bore a short stalklet at one extremity. A round or slightly oval structure (The chalaza) was carved on one side; two elongated and parallel deep groves incised the other (Martinoli, 2004).

Wild grapevines, also called as "jackal grapes" by villagers, are mostly grown on forest trees such as Liquadambar orientalis, Platanus orientalis, Pinus brutia and Ceretonia siliqua in the south-eastern corner of Turkey. Male plants are more prevalent than female wild plants (Uzun et al., 1998). 
86

V. sylvestris existed before the introduction of $V$. sativa into some countries in Europe, and even more V. sylvestris has a great number of biotypes in Anatolia and Caucasian Oraman (1952).

Alleweldt (1965) observed many biotypes of $V$. sylvestris in the western part of Turkey as a climbing plant on Pinus brutia, Platanus orientalis and Liquidambur orientalis.

V. sylvestris accessions growing in Turkey were described as follows: the flowers are dioecious; leaves are deciduous, palmately lobed and coarsely toothed. Male plants usually have more deeply lobed leaves than in the female ones. Berries as sour and have $5-7 \mathrm{~mm}$ in diameter, are blackisk-purple in color when ripe (Davis, 1967).

Schumann (1977) emphasized that he did not observe any powdery mildew damage on $V$. sylvestris vines during his study in eastern Turkey. These observations indicate that some wild grapevines could be resistant to powder mildew or other plant diseases.

Çelik et al. (2005a) collected 853 wild grapevine biotypes of $V$. sylvestris in coastal sides of Turkey. They stated

Tab. 1. Distribution of sylvestris by provinces in Turkey

\begin{tabular}{cc}
\hline Provices & References \\
\hline $\begin{array}{c}\text { Artvin, Hopa, Rize, Trabzon, Istanbul, } \\
\text { Izmir, Muğla, Silifke-Anamur }\end{array}$ & Oraman, 1952 \\
Köyceğiz, Fethiye, Gümüldür & Alleweldt, 1965 \\
$\begin{array}{c}\text { Kırklareli, Çanakkale, Istanbul, Sakarya, Amasya, Merzifon, } \\
\text { Kütahya,Elazıg, Izmir, Muğla Antalya, Seyhan, Hatay }\end{array}$ & Davis, 1967 \\
\hline $\begin{array}{c}\text { Trabzon, Bayburt, Gümüşhane, Diyarbakır, } \\
\text { Bitlis, Adıyaman, Kahta, Maraş }\end{array}$ & Schumann,1977 \\
Antalya & Uzun et al. , 1998 \\
\hline Mersin, Antalya, Muğla, Tekirdağ, Çanakkale & Çelik et al., 2005 \\
\hline
\end{tabular}

that wild grapes can also be used as rootstock. Bud take was over $65 \%$ for all grafting combinations

Ağaoğlu and Çelik (1987) noted that $V$. sylvestris can grow up to $1600 \mathrm{~m}$ altitude in central Anatolia. They are mostly dioecious and leaf form is generally circular with leaf width larger than the length. Leaf surface is nearly flat. Intensity of anthocyanin of shoot tip is medium (reddish color). Caucasian region and Black sea region of Turkey have rainy summer season. For this reason, wild grapes in these regions could be resistant to Plasmopara viticola fungus disease. Length of teeth is short. Berries are round in shape with black color.

\section{Cultivated grapes in Turkey}

Turkey is one of the main grape producers in the world, having aprox. 500.000 hectares as production area and 4 million tons as annual production.

A survey project started in 1965 by the Ministry of Agriculture aims to collect grape cultivars grown in Turkey and is still on role. Out of 1606 grape identified, 1100 cultivars have been conserved in national collection vineyard in Tekirdağ Viticultural Research Institute of the
Ministry of Agriculture. Out of this, only 70-80 cultivars are widely grown all over the country while the rest are local cultivars. Most of them are used as dried and table grapes or local consumptions. Widely grown rootstock varieties are 41B, 5BB, 110R, 99R and Rupestris du Lot (Çelik et al., 2005b).

The largest vineyard area in Turkey belongs to Sultana (Thompson seedless) grape cultivar which is white colored and seedless. It is produced in 85.000 hectares, with nearly 1.5 million tons production, which is equal to $40 \%$ of total grape production of the country. It is mostly used for raisin production and as table and wine grape on small procent. Turkey is the largest raisin producer and exporter, with 250.000 and 200.000 tons exported annually in the world, respectively. Aegean regions (Izmir, Manisa, Denizli) are the main production area. 'Razaki' group grapes ('Buca Razakisi,' 'Karaburun Razaki,' 'Mevlana' etc.) have the second largest production area. They are white colored, seeded grapes, and are mostly used as table and dried grapes.

Harvest season for grapevines starts at the beginning of June in the southern part of the country and continue until the end of November. Grapes are used for drying (40\%), table grape production (30\%), local consumptions (28\%) and wine production (2\%). Cold storage capacity for grapes is nearly of 10.000 tons. Sultana and Müssküle grape cultivars are the predominant grapes for cold storage. Each year nearly 130.000 tons of table grapes are exported to Russia and European countries.

Identification of the powdery mildew resistant gene (REN1) in cultivated grapes indicated that disease resistant genes could be found in old cultivars, which are useful for breeding programs when used as a parent (Coleman $e t$ al., 2009).

\section{Conclusions}

Turkey has a high potential for both wild and cultivated grapes. This potential should be used as a genetic material for improving grapevines in breeding studies mainly to biotic and abiotic stress factors. Firstly, these genetic materials must be surveyed and described for all potential characters before using them as genitors in grapevine breeding. Most of the cultivars were planted in national collection vineyard. Wild genotypes must urgently be collected and conserved in collection vineyards to protect them against the genetic erosion.

\section{References}

Ağaoğlu Y. S. and Çelik H., 1987. The work on the conservation of germplasm of the vine in Turkey. Results of GermanTurkish University Partnerships in the Agricultural Sector, p. 221-230. Göttingen Symposium (in German).

Alleweldt G. (1965). On the occurrence of wild grapes in Turkey. Zeitschrift für Pflanzenzüchtung 53(4):380-388 (in 
German).

Anonymous (2007). The national biological diversity strategy and action plan.

Anzani, R., O. Failla, A. Scienza and F. Campostrini(1989). Wild grapevine(Vitis vinifera var. sylvestris) in Italy: Diffusion, characteristics and germplasm preservation. $5^{\text {th }}$ Int. Symp. on grape breeding. Vitis special issue 1990:97-112.

Arroyo-García, R., L. Ruiz-García, L. Bolling, R. Ocete, M. A. López, C. Arnold, A. Ergul, G. Söylemezo"Lu, H. I. Uzun, F. Cabello, J. Ibáñez, M. K. Aradhya, A. Atanassov, I. Atanassov, S. Balint, J. L. Cenis, L. Costantini, S. Gorislavets, M. S. Grando, B. Y. Klein, P. E. Mcgovern, D. Merdinoglu, I. Pejic, F. Pelsy, N. Primikirios, V. Risovannaya, K. A. Roubelakis-Angelakis, H. Snoussi, P. Sotiri, S. Tamhankar, P. This, L. Troshin, J. M. Malpica, F. LefOrt and J. M. Martinez-Zapater(2006). Multiple origins of cultivated grapevine (Vitis vinifera L. ssp. sativa) based on chloroplast DNA polymorphism. Molecular ecology. 15:3707-3714.

Coleman, C., D. Copetti, G. Cipriani, S. Hoffman, P. Kozma, L. Kovacs, M. Morgante, R. Testolin and G. Di Gaspero. (2009). The powdery mildew resitance gene RENI cosegregates with an NBS-LRR gene cluster in two Central Asian grapevines. BMC genetics 10(89):1-20.

Çelik S., B. Elman, I. Korkutal and D. Kök (2005a). Wild vine that grows naturally in Turkey ( $V$. vinifera ssp. sylvestris) described a study on the massive opportunities in production, p. 22-31. VI Turkey Viticulture Sympoium (in Turkish).

Çelik H., S. Çelik, BM: Kunter, G. Söylemezoğlu, Y. Boz, C. Özer, and A. Atak (2005b). Viticulture development and production targets, p. 565-588. VI Turkey Agricultural Eng. Technical Symposium (in Turkish).

Davis, P. H. (1967). Flora of Turkey and east Aegean Islands 2:521-522.

Grassi, F., M. Labra, S. Imazio, A. Spada, S. Sgorbati, A. Scienza and F. Sala (2003). Evidence of seondary grapevine domestication centre detected by SSR analysis. Theor. Appl. Genet. 107:1315-1320.

Güner, A., G. Gyulai, G. A. Başlı, Z. Toth, L. Waters, Z. Szabo, L. Heszky, A. Bittsanszky and F. Gyulai (2009). Grape(Vitis vinifera) seeds from Antiquity and the Middle Ages excavated in Hungary-LM and SEM analysis. Anadolu Univ. J. Sci.and Tech. 10(1):205-213.

Imazio, S. F., De Mattia, M. Labra, O. Failla, A. Scienza and F.Grassi (2009). Biodiversity and Conservation of Vitis vinifera ssp. sylvestris. Acta Horticulturae 827:95-102.

Jacquat, C. and D. Martinoli (1999). Vitis vinifera L.: wild or cultivated? Study of the grape pips found at Petra, Jordan. Veget. Hist. Archaeobot. 8:25-30.

Mc Govern, P., S. Fleming and S. Katz (1996). The origins and ancient history of wine. Gordon and Breach publishers.

Maghradze, D. , M. Rossoni, S. Imazio, C. Maitti, O. Failla, F. D. Zan, N. Chkhartishvili and A. Scienza (2009). Genetic and phenetic exploration of Georgian grapevine germplasm. Acta Horticulturae 827:107-111.

Martinoli, D. (2004). Food plant use, temporal changes and site seasonality at epipaleolithic Öküzini and Karain B caves, southwest Anatolia, Turkey. Paleorient. 30(2):61-80.

Miller, N. (2008). Sweeter than wine? The use of the grape in early western Asia. Antiquity 82:937-946.

Negi, S. S. and H. P. Olmo (1970). Studies on sex conversion in male Vitis vinifera L. (sylvestris). Vitis 9:89-96.

Oceta, R., M. A. Lopez, A. Gallardo and C. Arnold (2008). Comparative analysis of wild and cultivated grapevine(Vitis vinifera) in the Basque region of Spain and France. Agriculture, Ecosystems and Environment 123:95-98.

Oraman, N. (1952). Old and new research on the origin of wild vine. A.Ü. Faculty of Agriculture Yearbook 2(2-3):252-257 (in Turkish).

Schumann V.F. (1977). Notes on the occurrence of wild grapes in Turkey. The Wine Science 32(3):169-173 (in German).

Scienza, A., P. Villa, G. Tedesco, L. Parini, C. Ettori, S. Magenes and E Gianazza (1994). A chemotaxonomic investigation on Vitis vinifera L. II. Comparison among ssp.sativa traditional cultivars and wild biotypes of ssp. sylvestris from various Italian regions. Vitis 33:217-224.

This, P., C. Roux, P. Parra, R. Siret, T. Bourse, A. F. Adam, M. Yvon, T. Lacombe, J. David and J. M. Boursiquot (2001). Characterization of genetic diversity in a population of wild grapes from nPic Saint Loup areaand its relationship with the cultivated grapes. Genet. Select. Evol. 33:289-304.

This, P., T. Lacombe and M. Thomas (2006). Historical origins and genetic diversity of wine grapes. Trends in Genetic 22(9):511-519.

Troshin, L. P., P. N. Nedov, A. F. Litrak and N. I. Guzun (1990). Improvement of Vitis vinifera sativa D.C. taxonomy. $5^{\text {th }}$ Int. Symp. on grape breeding. Vitis special issue 37-43.

Tsvetkov, I., A. Atanassov, M. Jankulova, V Vulchev, I.Todorov, S. Pandeliev, K. Katerov, I Atanassov, T. Hvarleva, Y. Tsvetkov, I. Genov, T. Dzambazova, I. Antonov, L. Marinov, E. Dimitrov, M. Panamska, G. Varadinova, K. Slavova, I. Atanassov, G. Shishmanov, N. Ivanova and M. Laginova. (2005). Plant genetic resources- improvement, preservation and biodiversity. Biotechnol \& Biotechnol Eq. 19:13-21.

Uzun, H. I., S. Ağaoğlu and G. Söylemezoğlu (1998). Ampelographic characteristics and isozymic analysis of wild grapevines (Vitis vinifera ssp. sylvestris Gmel) in Southwestern Turkey. Proc. Int Symp. In situ Conserv. Plant Genetic Diversity 163-169.

Vecchi-Staraz, M., V. Laucou, G. Bruno, T. Lacombe, S. Gerber, T. Bourse, M. Boselli and P. This (2009). Low level of Polenmediated gene flow from cultivated to wild grapevine: consequences for the evalution of the endangered subspecies Vitis vinifera L. subsp. sylvestris. Journal of Heredity 100(1):66-75.

Zohary, D. and M. Hopf (2000). Domestification of plants in the old world. Oxford Univ. Press.

Zohary, D. (2004). The domestification of the grapevine Vitis vinifera L. in the Near East, pp. 23-31. In: Mc Govern P., S. Fleming and S. Katz (Eds.) . The origins and ancient history of wine. Gordon and Breach Publishers, London. 